Natural Hazards and Earth System Sciences (2002) 2: 51-56

(C) European Geophysical Society 2002

\title{
Landslides density map of S. Miguel Island, Azores archipelago
}

\author{
P. Valadão ${ }^{1}$, J. L. Gaspar ${ }^{1}$, G. Queiroz ${ }^{1}$, and T. Ferreira ${ }^{1}$ \\ ${ }^{1}$ Centro de Vulcanologia e Avaliação de Riscos Geológicos, Departamento de Geociências, Universidade dos Açores, Rua \\ Mãe de Deus, 9501-801 Ponta Delgada, Portugal
}

Received: 6 August 2001 - Revised: 7 January 2002 - Accepted: 15 January 2002

\begin{abstract}
The Azores archipelago is located in the Atlantic Ocean and is composed of nine volcanic islands. S. Miguel, the largest one, is formed by three active, E-W trending, trachytic central volcanoes with caldera (Sete Cidades, Fogo and Furnas). Chains of basaltic cinder cones link those major volcanic structures. An inactive trachytic central volcano (Povoação) and an old basaltic volcanic complex (Nordeste) comprise the easternmost part of the island.

Since the settlement of the island early in the $15^{\text {th }}$ century, several destructive landslides triggered by catastrophic rainfall episodes, earthquakes and volcanic eruptions occurred in different areas of S. Miguel. One unique event killed thousands of people in 1522. Houses and bridges were destroyed, roads were cut, communications, water and energy supply systems became frequently disrupted and areas of fertile land were often buried by mud.

Based on (1) historical documents, (2) aerial photographs and (3) field observations, landslide sites were plotted on a topographic map, in order to establish a landslide density map for the island. Data obtained showed that landslide hazard is higher on (1) the main central volcanoes where the thickness of unconsolidated pyroclastic deposits is considerable high and (2) the old basaltic volcanic complex, marked by deep gullies developed on thick sequences of lava flows. In these areas, caldera walls, fault scarps, steep valley margins and sea cliffs are potentially hazardous.
\end{abstract}

\section{Introduction}

The Azores archipelago is located in the North Atlantic Ocean between $37^{\circ}-40^{\circ} \mathrm{N}$ latitude and $25^{\circ}-31^{\circ} \mathrm{W}$ longitude. It comprises nine volcanic islands and is situated where the American, Eurasian and African lithospheric plates meet (Fig. 1). The main tectonic structures that can be defined in this area are: (1) the Mid-Atlantic Ridge, which crosses the archipelago between the islands of Flores and Faial; (2) the

Correspondence to: P. Valadão (pv@ notes.uac.pt)
East Azores Fracture Zone, that extends E-W from the MidAtlantic Ridge to Gibraltar; and (3) the Terceira Rift, which trends NW-SE from the Mid-Atlantic Ridge to N of Santa Maria Island. Several authors have studied the Azores Triple Junction and different geodynamic models have been proposed (Madeira and Ribeiro, 1990). The structural behaviour of the Terceira Rift, including the WNW-ESE Faial-Pico and S. Jorge fractures, is still a controversial issue (Fig. 2).

Due to its geographical location and geological setting, the Azores were affected by several natural catastrophes since its settlement in the $15^{\text {th }}$ century. Destructive earthquakes, volcanic eruptions and landslides that occurred in historical times were responsible for many deaths and substantial damage.

S. Miguel is located at the eastern end of the Terceira Rift and is marked by NW- SE, NE-SW and WNW-ESE tectonic features. E-W fault trends also occur and have been interpreted as reflecting deep oceanic structures (Queiroz, 1997). The distribution of volcanic vents on the island is strongly related to tectonics, with active trachytic stratovolcanoes located at the intersection of the main faults' systems, whereas cinder cones form impressive basaltic chains among the former major volcanic structures (Fig. 3).

S. Miguel, the most populated island of the archipelago, has a very high risk for earthquakes, volcanic eruptions and landslides. This paper is part of a project about the geological hazard mapping of S. Miguel Island and explores the landslide problem, especially trigger mechanisms and the geological environment.

\section{Methodology}

In order to produce this report, historical documents, newspapers, essay articles and scientific papers related to landslides observed on S. Miguel were collected, analysed and stored in digital form for later consultation. At the same time, and based on some published models proposed for other regions (e.g. Fossati et al., 2000; Antonini et al., 2000; Chowdhury 


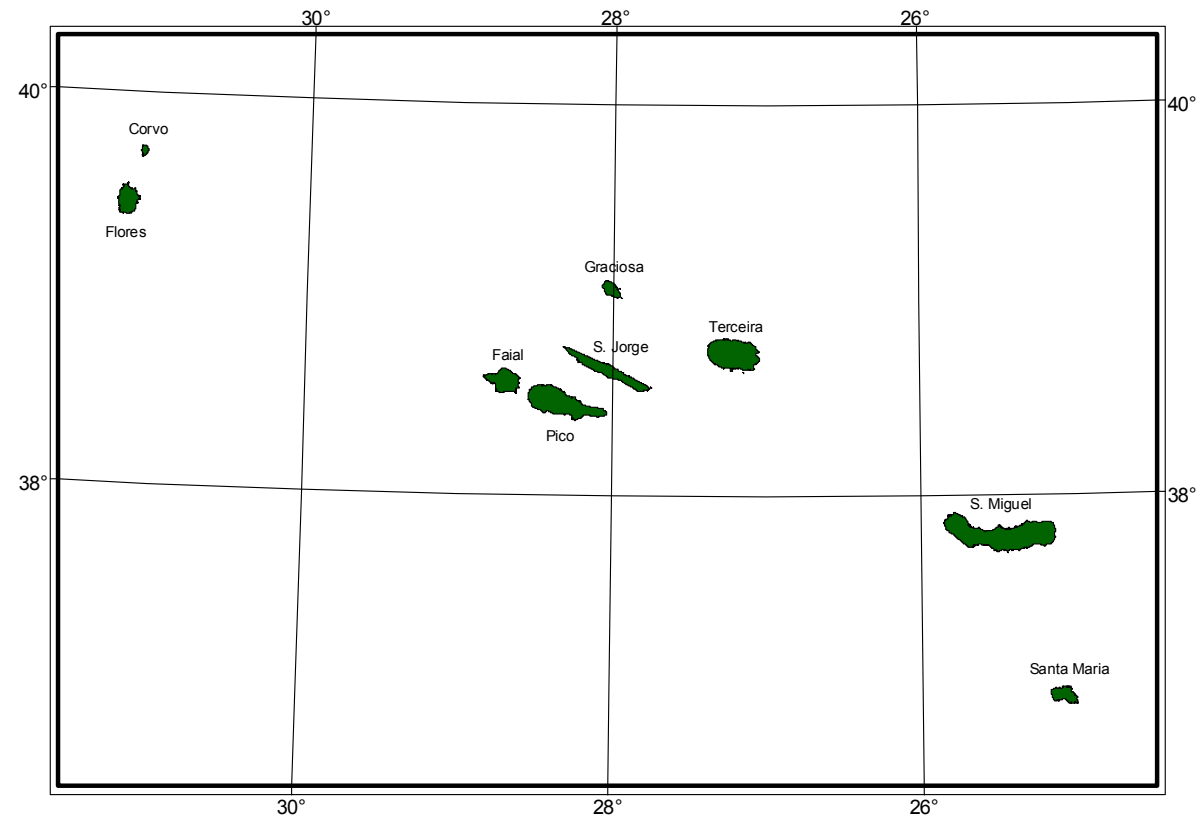

Fig. 1. Geographical location of Azores archipelago.

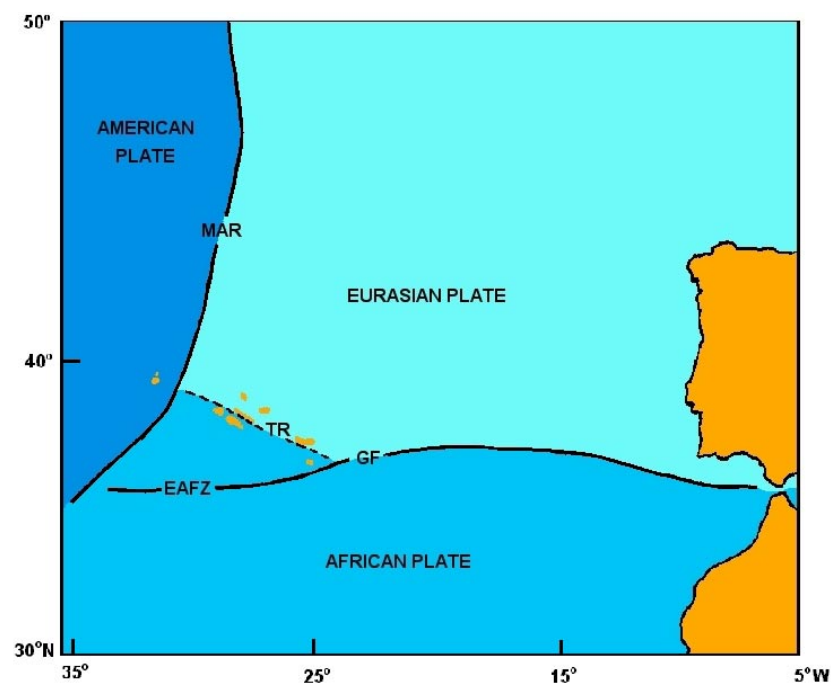

Fig. 2. Main tectonic structures that can be defined in the area of the Azores Triple Junction. MAR (Mid-Atlantic Ridge); EAFZ (East Azores Fracture Zone); TR (Terceira Rift) (adapted from: Gaspar et al., 1999).

and Flentje, 1998; Cruden and Brown, 1992), a database was developed in order to include all the information needed to characterize such type of phenomenon.

The landslide mapping of S. Miguel Island was made through the observation of aerial photographs and field surveys. The identification of landslide by aerial photographs was based on morphological criteria, such as the presence of scars and in some places, the existence of an associated deposit. Aerial photographs taken in 1974, 1977, 1995 and 1998 (1:8000 and 1:15000 scales) were analysed according to the above criteria, giving the possibility of establishing intervals of occurrence of certain events. All identified landslides (2818 events) were plotted on a topographic map (at 1:25000 scale) and then were entered into a Geographical Information System (GIS), where each event, represented by a dot, has an associated information sheet. A Landslide Density Map produced using this tool (Fig. 4) helps explain hazard and risk assessment.

The field surveys had the objective of characterizing the main events (higher magnitude and/or the most recent ones) and, therefore, define its respective setting in terms of geological structures, kinds of volcanic deposits and human influence.

\section{Historical accounts}

Among the most important historic landslides that occurred on S. Miguel, the ones in 1522, 1630 and 1997 should be mentioned, not only due to their magnitude, but also to the loss of lives and/or destruction.

A very strong earthquake hit Vila Franca do Campo, the capital of the island at the time, on 22 October 1522. The epicentre was S of Vila Franca do Campo and the event had magnitude X on the Mercalli Modified Scale (Machado, 1966). This earthquake triggered a landslide on a hill saturated by water, which buried most of the village and killed near 5000 people (almost everyone who lived there at the time).

Approximately one century later (3 September 1630) a volcanic eruption took place in the Furnas volcano. The eruption fluctuated between magmatic (subplinian) and phreatomagmatic episodes. Explosive activity was followed by the growth of a lava dome (Cole et al., 1995). Precursory earthquakes were felt a few hours before the beginning of 

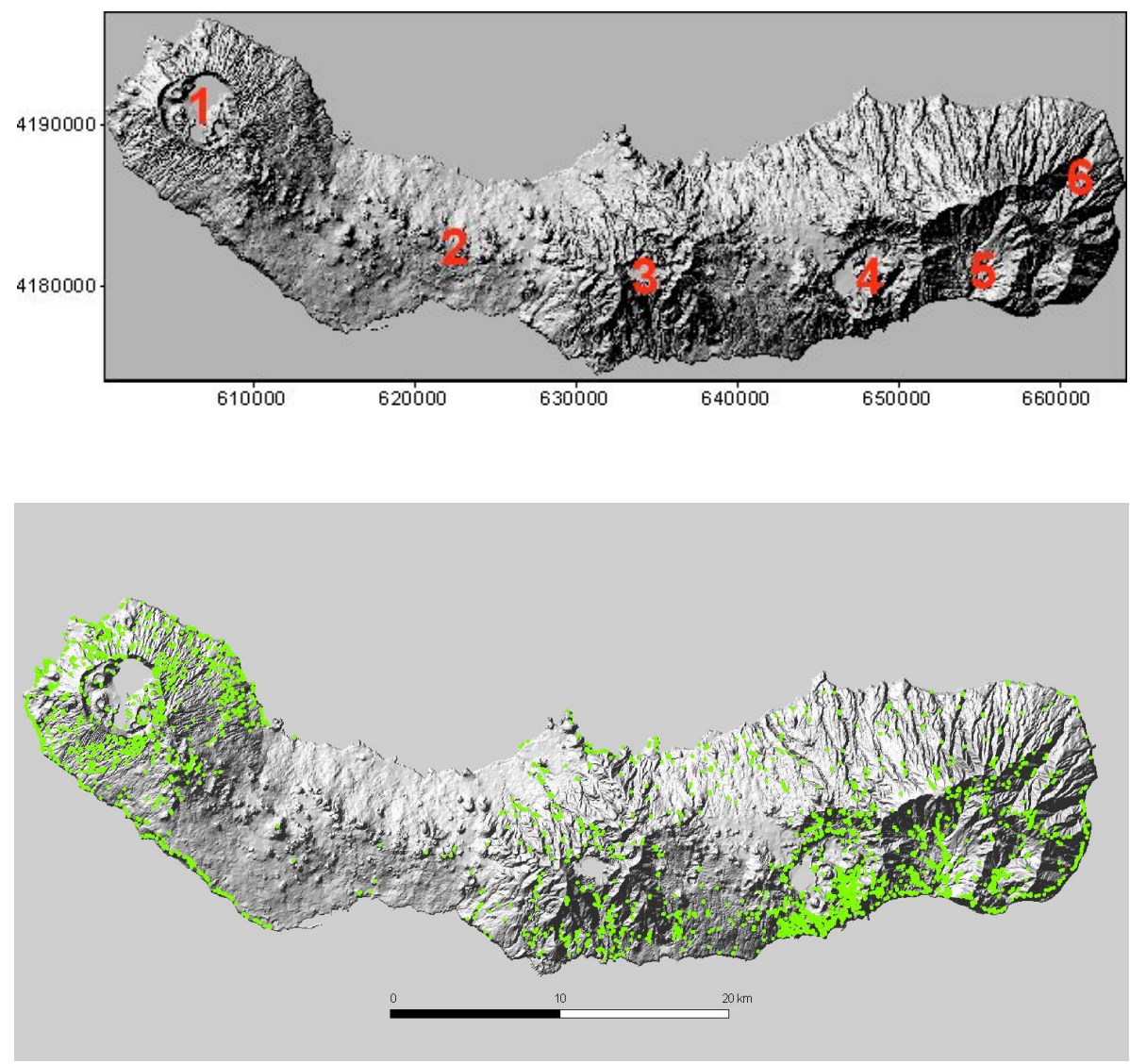

Fig. 3. Main morphological provinces on S. Miguel Island: (1) Sete Cidades Volcano, (2) Volcanic System of Picos Region, (3) Fogo Volcano, (4) Furnas Volcano, (5) Povoação Volcano and (6) Nordeste Volcanic Complex.
Fig. 4. Landslide Density Map for S. Miguel Island, Azores archipelago. Each green dot represents one landslide. A total of 2818 events are shown.

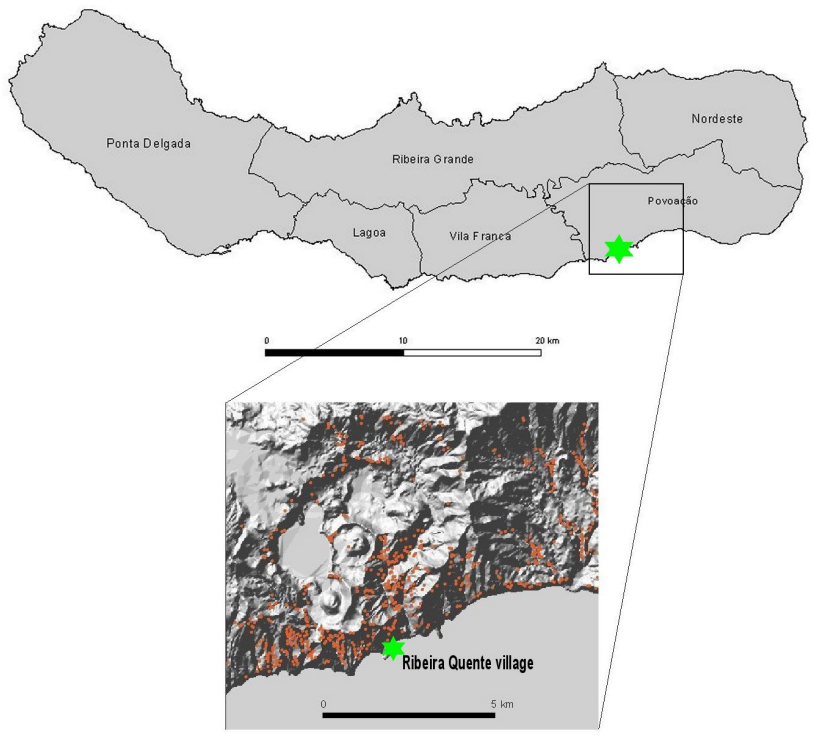

Fig. 5. Landslide density map for the landslides occurred in $31 \mathrm{st}$ October 1997, at Povoação county. The green star represents the location of Ribeira Quente village.

the eruption (Corrêa, 1924; Jerónimo, 1989). Some of them caused "the hills to move" and "the land ran to the sea, entering the sea for 200 meters" (Jerónimo, 1989). Cole et al.
(1995) interpreted these descriptions as being related to the landslide event that produced the debris flow deposit that underlies the 1630 AD tephra on the beach at Ribeira Quente. At that time, Ribeira Quente was apparently not permanently inhabited as it is today.

On 31 October 1997, nearly 1000 landslides occurred on S. Miguel Island, a few of them killing 29 people who were living in the Ribeira Quente village (Fig. 5). Povoação and Nordeste counties were particularly affected during this event (Gaspar et al., 1997; Gaspar and Guest, 1998). Several houses and bridges were partially or totally destroyed, communications, transportation and the energy supply system were disrupted and areas of fertile land became covered by mud (Fig. 6). Ribeira Quente village was isolated for more than $12 \mathrm{~h}$ (Fig. 7).

The main cause of this large-scale phenomenon was a local and catastrophic rainstorm. The strong SE winds that accompanied the heavy rain and the vulnerability of the volcanic soils, already saturated as a result of long periods of continuous precipitation, certainly contributed to the magnitude of the event (Gaspar and Guest, 1998).

Most of the landslides were essentially very fluid debris flows, consisting of a mixture of water, pumice and ash. Trees with their root systems, tree trunks and branches were included in most deposits. Depending on the source, some debris flows included large blocks of lava. 


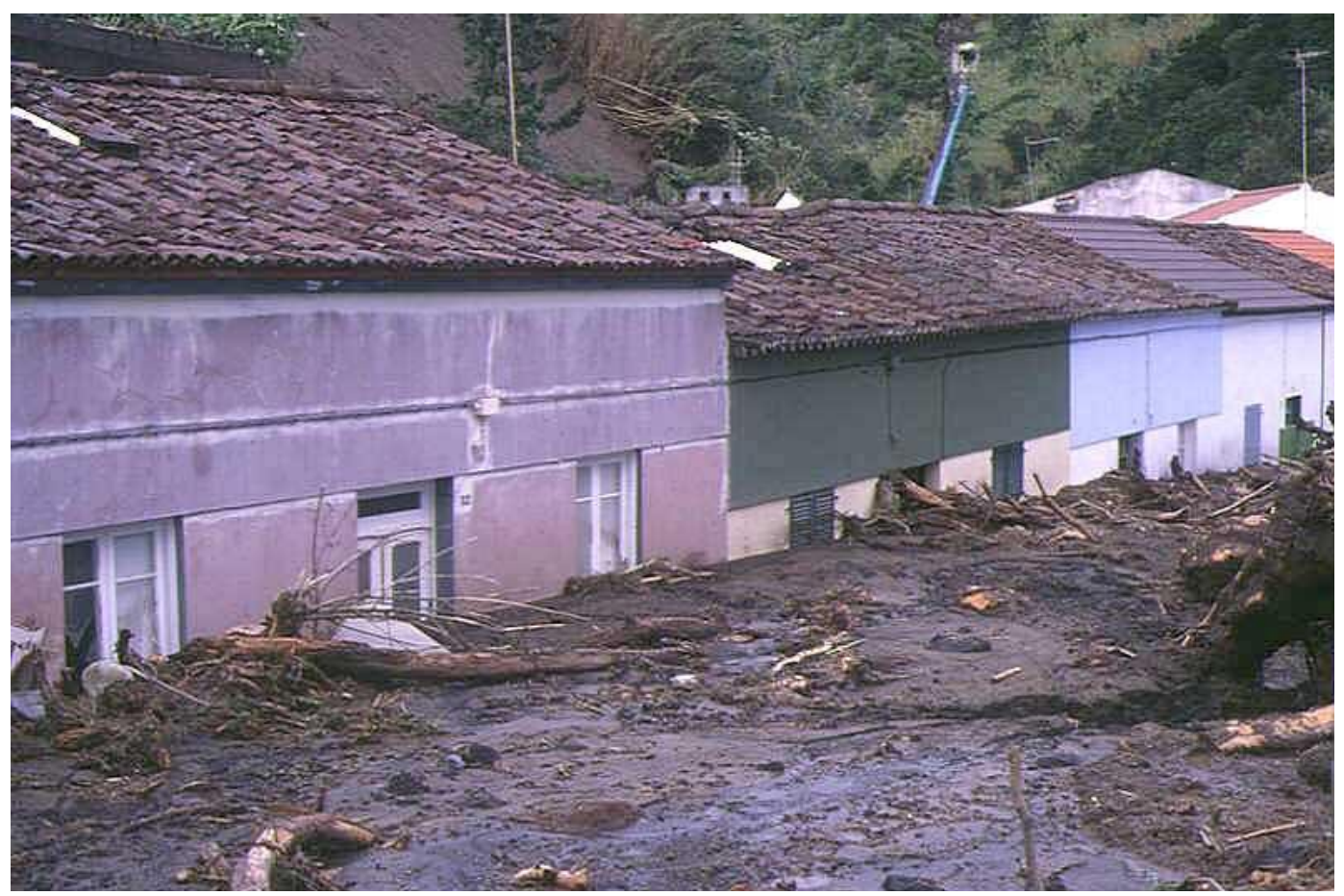

Fig. 6. Houses affected by debris flows during the 1997 Ribeira Quente event.

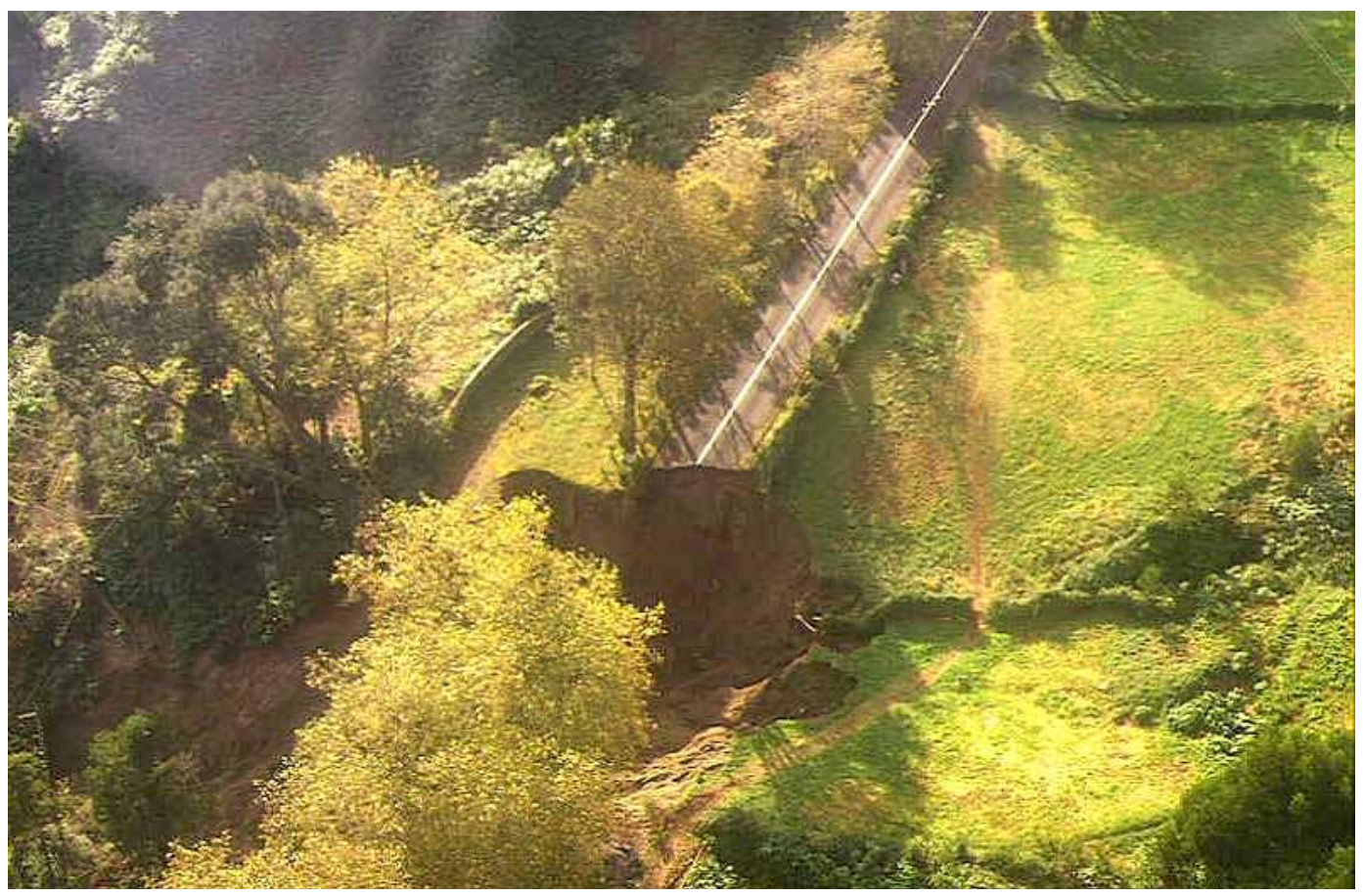

Fig. 7. Road cut by the collapse of the edge of a streamline at Furnas Volcano, during the 1997 Ribeira Quente event. 


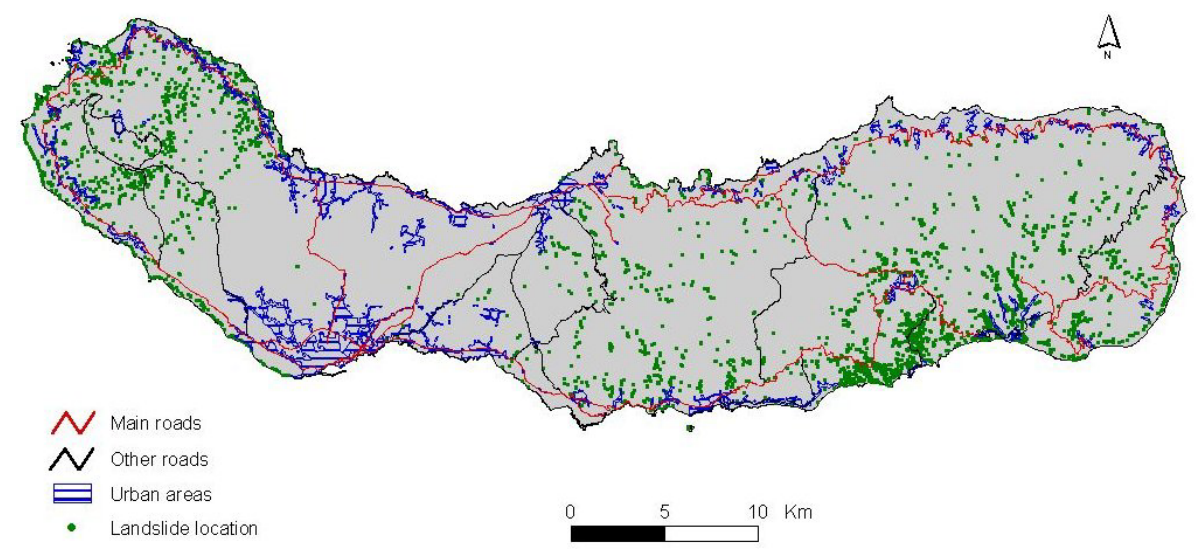

Fig. 8. Landslide Risk Map for S. Miguel Island, Azores archipelago.
Although there were some exceptions, the majority of the landslides originated on very steep slopes, with small thickness but considerable length.

\section{Discussion}

The reported historical accounts emphasize the high potential landslide hazard on S. Miguel Island, triggered by catastrophic rainfall episodes, earthquakes and volcanic eruptions.

It is clear, from the analysis of the Landslide Density Map that most landslides are related to the young central volcanoes and sea cliffs in their vicinity. Vertical caldera walls, relatively steep slopes, deep streamlines and several fault scarps characterize these central volcanoes, which are covered by unconsolidated pyroclastic deposits from recent explosive eruptions. The old basaltic volcanic complex of Nordeste, marked by deep gullies developed on thick sequences of lava flows, some of them very altered, also has a high number of landslides.

On the other hand, the volcanic system of the Picos Region shows the lowest concentration of landslide events. This is due to the fact that this area is mainly built up by recent basaltic lava flows, with minor interbedded scoria deposits, presenting gentle slopes and just a few immature valleys.

\section{Conclusions}

The historical bibliographic analysis done in this work shows that S. Miguel is very vulnerable to natural catastrophes as a result of its geographical location and geological setting. Earthquakes, volcanic eruptions and landslides have marked the island's history over the last 500 years, resulting in thousands of deaths and significant damage. Landslides were triggered by rainfall episodes, earthquakes and volcanic eruptions and occurred with special incidence at the main central volcanoes and at the old basaltic volcanic complex.

The superimposition of the main cities, villages and basic infrastructures of S. Miguel on the Landslides Density Map emphasizes the high risk that exists in certain areas of the island (Fig. 8). Emergency and land use planning are needed in order to minimize the impact of future complex/multiple events. Authorities should be aware of the importance of hazard and vulnerability assessment to ensure the normal socio economic development of the region.

Following this work, other studies are in progress in order to produce landslide hazard/risk maps for S. Miguel Island. This includes numerical and statistical analysis (e.g. Carrara et al., 1978; Carrara, 1983; Leroi, 1996), isopleths mapping (e.g. Bulut et al., 2000; De Graff and Canuti, 1988; Wright et al., 1974) and geotechnical models (e.g. Chowdhury, 1984; Hammond et al., 1992, Wu and Abdel Latif, 1994; Nguyen and Chowdhury, 1995), considering variables such as geology, lithology, slope and soil resistant properties.

Acknowledgements. This work was supported by the Azores Regional Government through the Secretaria Regional da Habitação e Equipamentos and is part of the project Carta de Riscos Geológicos da Região Autónoma dos Açores.

\section{References}

Aleotti, P. and Chowdhury, R.: Landslide hazard assessment: summary review and new perspectives, Bull. Eng. Geol. Env., 58, 21-44, 1999.

Antonini, G., Ardizzone, F., Cacciano, M., Cardinali, M., Castellani, M., Galli, M., Guzzetti, F., Reichenbach, P., and Salvati, P.: A geomorphological approach to estimate landslide hazard and risk in urban and sub-urban areas: examples from the Umbria region, European Geophysical Society, XXVI General Assembly, Nice, 2000.

Bulut, F., Boynukalin, S., Tarhan, F., and Ataoglu, E.: Reliability of landslide isopleth maps, Bull. Eng. Geol. Env., 58, 95-98, 2000.

Carrara, A., Catalano, E., Sorriso-Valvo, M., Reali, C., and Ossi, I.: Digital terrain analysis for land evaluation, Geologia Applicata e Idrogeologia, 13, 69-127, 1978.

Carrara, A.: Multivariate methods for landslide hazard evaluation, Mathematical Geol., 15, 403-426, 1983.

Chowdhury, R. N.: Recent developments in landslide studies: probabilistic methods - state-of-the-art-report, in: Proc. IV Int. Symp. Landslides, Toronto, 1, 209-228, 1984. 
Chowdhury, R. N. and Flentje, P.: A landslide database for landslide hazard assessment, in: Workshop on landslide hazard assessment - Progressing from qualitative to quantitative approaches, Wollongong, 1998.

Cole, P. D., Queiroz, G., Wallenstein, N., Gaspar, J. L., Duncan, A. M., and Guest, J.: An historic subplinian/phreatomagmatic eruption: the $1630 \mathrm{AD}$ eruption of Furnas volcano, S. Miguel, Azores, J. Volcanol. Geotherm. Res., 69, 117-135, 1995.

Corrêa, J.: Leituras sobre a história do Vale das Furnas, Oficina de Artes Gráficas, S. Miguel, Açores, 217, 1924.

Cruden, D. M. and Brown, W. M.: Progress towards the World Landslide Inventory, in: Proc. VI Int. Symp. Landslides, Christchurch, 1, 59-64, 1992.

DeGraff, J. and Canuti, P.: Using isopleth mapping to evaluate landslide activity in relation to agricultural practices, Bull. Int. Ass. Eng. Geol., 38, 61-71, 1988.

Fossati, D., Mazzoccola, D., Sciesa, E., and Ceriani, M.: Precedure per la valutazione e la zonazione della pericolositá e del rischio da frana in regione lombardia, Bollettino Ufficiale Regione Lombardia, Milano, 51, 63, 2000.

Fructuoso, G.: Livro Quarto das Saudades da Terra, Ed. Instituto Cultural de Ponta Delgada, 1977, 1-2. 1583.

Gaspar, J. L., Wallenstein, N., Coutinho, R., Ferreira, T., Queiroz, G., Pacheco, J., Guest, J., Tryggvason, E., and Malheiro, A.: Considerações sobre a ocorrência dos movimentos de massa registados na madrugada de 31 de Outubro de 1997 na ilha de S. Miguel, Aores, Relatório Técnico-Cientifico 17/DGUA/97, centro de Vulcanologia, 28, 1997.

Gaspar, J. L. and Guest, J.: The $31^{\text {st }}$ October 1997 landslides at S. Miguel Island, Azores: a dramatic lesson for the future, Volcanic Hazard Assessment, Monitoring and Risk Mitigation; Advanced
Study Course, European Commission, 43, 1998.

Gaspar, J. L., Trota, A., Queiroz, G., Ferreira, and T. e Alves, P.: Plano Municipal de Emergência da Vila do Porto, Câmara Municipal de Vila do Porto, Ilha de Santa Maria. Centro de Vulcanologia da Universidade dos Açores, 1999.

Hammond, C., Prellwitz, R., and Miller, S.: Landslide hazard assessment using Monte Carlo simulation, in: Proc. VI Int. Symp. Landslides, Christchurch, 2, 959-964, 1992.

Jerónimo, G. M.: Nós, açorianos e os sismos, Correio dos Açores, 1989.

Leroi, E.: Landslide hazard - Risk maps at diferent scales: objectives, tools and developments, in: Proc. VII Int. Symp. Landslides, Trondheim, 1, 35-52, 1996.

Machado, F.: Anomalias das intensidades do terramoto de S. Miguel (Aores) em 1522, Bol. Mus. Lab. Min. Geol. Fac. Ciên. Lisboa, 10, 2, 109-117, 1966.

Madeira, J. and Ribeiro, A.: Geodynamic models for the Azores Triple Junction: a contribution from tectonics, Tectonophysics, 184, 405-415, 1990.

Nguyen, V. and Chowdhury, R.: Risk analysis with correlated variables, Geotechnique, 35, 47-59, 1995.

Queiroz, G.: Vulcão das Sete Cidades (S. Miguel, Açores), História eruptiva e avaliação do hazard, Tese de Doutoramento, Universidade dos Açores, 226, 1997.

Wright, R. H., Campbell, R. H., and Nilsen, T. H.: Preparation and use of isopleth maps of landslides deposits, Geology, 2, 483-485, 1974.

Wu, T. H. and Abdel-Latif, M. A.: Prediction, mapping and updating of landslide hazard, Proc. Conf. On Deep Foundation Ground Improvement, AIT Bangkok, 1994. 